https://doi.org/10.15407/frg2019.05.415

UDC 631.847.211:633.31:631.81

\title{
EFFICIENCY OF INOCULATION BY NODULE BACTERIA OF ALFALFA GROWN IN MIXTURE WITH SMOOTH BROMEGRASS AT VARIOUS RATES OF PHOSPHORUS AND POTASSIUM NUTRITION
}

\author{
P.P. PUKHTAIEVYCH ${ }^{1}$, E.P. KUKOL ${ }^{1}$, N.A. VOROBEY ${ }^{1}$, V. VASILEVA ${ }^{2}$, \\ S.Ya. KOTS ${ }^{1}$ \\ ${ }^{1}$ Institute of Plant Physiology and Genetics, National Academy of Sciences of \\ Ukraine \\ 31/17 Vasylkivska St., Kyiv, 03022, Ukraine \\ e-mail: azot@ifrg.kiev.ua \\ ${ }^{2}$ Institute of Forage Crops, \\ 89 General Vladimir Vazov St., Pleven, 5800, Bulgaria \\ e-mail: viliana.vasileva@gmail.com
}

Under the conditions of pot experiment it was studied the efficiency of alfalfa inoculation by nodule bacteria Sinorhizobium meliloti B-7411 while growing alfalfa in mixture with smooth bromegrass at varying norms of phosphoric-potassium nutrition. It was found that symbiotic alfalfa systems that were formed with the strain $S$. meliloti B-7411 differed in $\mathrm{N}_{2}$ assimilation rate depending on dosage of phosphorus and potassium nutrition (PK), but had similar dynamics of increase of this index from stems formation to flowering stage. A number and weight of root nodules on alfalfa, at double dose of PK was reduced, which led to a decrease of biological atmospheric nitrogen fixation. The highest level of $\mathrm{N}_{2}$ assimilation by alfalfa root nodules was found in the periods of stems formation, budding and flowering at the background of 1 norm phosphorus and potassium (by Helrigel), and the decrease of this index in 2.6, 3.6 and 2.9 times observed at the corresponding stages at the background of 2 norms of PK. Bacterization of alfalfa seeds contributed to the growth of the aboveground plant mass of both mixture components. The greater yield of green mass and dry matter was obtained in treatments with presowing inoculation of seeds by rhizobia $S$. meliloti B-7411 and with 1 dose of phosphorus and potassium without inoculation as compared to treatments with higher doses of PK (1.5 and $2 \mathrm{n}$ ). Positive dynamics of aboveground mass growth of smooth bromegrass was also observed during its cultivation in mixture with alfalfa, for different rates of input of phosphorus and potassium. At the same time, the smallest values of plants green mass growth of the grass component of mixture were also obtained for the double norm of PK.

Key words: Sinorhizobium meliloti, alfalfa, smooth bromegrass, phosphorus, potassium, inoculation, nitrogen fixation, productivity. 
Legumes, owing to symbiotic $\mathrm{N}_{2}$ fixation can form high yield of cheap plant protein without usage of expensive, power-consuming and non ecofriendly mineral $\mathrm{N}$ fertilizers. After crop harvesting more than $30 \%$ of fixed $\mathrm{N}$ are kept in plant residues and roots and can be used by next cultures of crops rotation [1].

Considering that $\mathrm{N}_{2}$-fixing potential of symbiosis of legumes and nodule bacteria attended in soil is frequently limited by low activity of bacteria or their small amount in zone of seed germination, presowing treatment of seed material is carried out by biological products based on selected, competitive strains, that increase productivity of plants and promote introduction of highly efficient nodule bacteria to soil microbiota [2].

It is well-known that seed inoculation with bacterial products has positive effects on general state of plants: they have better biometrical indices, intensive metabolic processes, in particular photosynthesis and $\mathrm{N}_{2}-$ fixation, increased resistance to phytopathogens [3, 4].

Characteristic feature of alfalfa as a legume plant is an opportunity to symbiosis with Sinorhizobium meliloti bacteria, which are facultative $\mathrm{N}_{2}$-fixator, that can be soil saprophyte without host plant or can form symbiosis. The most productive symbiosis arises in a case of co-evolution of host plant and microorganism [3, 5].

In order to obtain stable and high quantity of forage units and mineral $\mathrm{N}_{2}$ fertilizer savings, scientists recommend to sow mixtures of alfalfa or clover with smooth bromegrass, orchard grass, meadow fescue or oat-grass. It is proved that mixtures of legumes with grasses which include species of different families and biological groups provide higher and more stable yield than pure grown crops $[6,7]$. But scientists also noticed a decrease of $\mathrm{N}_{2}$-fixation performance, when even one kind of grasses was added to the mixture. This is explained by the fact of high usage of $\mathrm{N}$ by grasses. Reserves of $\mathrm{N}$ in nodules and root excretion used by mixture with high percent of grasses are getting lower [8]. Broadly, the question about effect of grass species in mixture on symbiotic $\mathrm{N}_{2}$ fixation by legumes is badly shown in science literature.

Quantity of $\mathrm{N}_{2}$ that can be fixed by alfalfa varies widely depending on physical, chemical properties of soil and agricultural background [9]. Phosphorus and potassium located in soil cause significant influence on plants growth and development [10, 11, 12]. Their lack causes different violations of metabolic processes of plants that lead to growth retardation $[11,13]$. Phosphorus deficiency causes decrease of phosphorus-containing organic compounds, respiration activity and limit penetration of nodule bacteria into legumes roots [10]. Leaf darkening and appearance of violet-purple or bronze colour on leaves and later on stems are also noticed [13].

Presence of potassium in soil is a necessary condition for increasing different plant resistances - cold resistance, drought resistance, resistance to different disease-producing factors and pests. Potassium deficiency disturbs water relationships in plants and their growth. For example, chlorosis and necrosis appear on old leaves that removed their potassium to young growing plant organs. Leaves are looked burnt. Plants loose their turgor pressure and fade [11]. 
A lot of researches devoted to studying of the influence of phosphorus and potassium fertilizers on legume-rhizobial symbiosis formation and functioning, but only some of them concerned alfalfa plants. According to [13], lack of phosphorus in soil inhibits growth of nodules more than growth of stems. In the same time phosphorus concentration in nodules changed less than it concentration in other plant organs, wich grew up with its lack.

Looking at the above, there is a need of careful studying of influence of phosphorus and potassium variable doses on processes of symbiotic apparatus formation, plant growth and development, $\mathrm{N}_{2}$ fixation rates, and productivity of crop mixtures.

The aim of our work was to evaluate the effectiveness of alfalfa inoculation by nodule bacteria in mixtures with smooth bromegrass under the varying doses of phosphorus and potassium.

\section{Methods}

The experiments were carried out with potted plants of alfalfa (Medicago sativa L.) and smooth bromegrass (Bromus inermis Leyss., Institute of forage crops, Pleven, Bulgaria). Mixture of plant species (1:1) was grown in 141 plastic pots under natural light and temperature on the plant growing ground of Institute of Plant Physiology and Genetics of NAS of Ukraine (Kyiv, Ukraine). Pots was sterilized by $20 \%$ solution of $\mathrm{H}_{2} \mathrm{O}_{2}$. The substrate for growing was river sand. The source of mineral nutrition was Helrigel mixture, enriched by microelements: molybdenum, boron, copper, but it was nitrogen-depleted -0.25 of norm ( 1 norm is $708 \mathrm{mg} \mathrm{Ca}\left(\mathrm{NO}_{3}\right)_{2}$ - $4 \mathrm{H}_{2} \mathrm{O}$ for $1 \mathrm{~kg}$ of sand). The plan of research included variants with the applications of 1, 1.5 and 2 norms of $\mathrm{KH}_{2} \mathrm{PO}_{4}$ by Helrigel [14]. For presowing inoculation of alfalfa seeds, the strain of Sinorhizobium meliloti B7411 [15] from the collection of $\mathrm{N}_{2}$-fixing microorganisms of the Institute of Plant Physiology and Genetics of NAS of Ukraine was used.

To prepare inoculum suspension, biomass of bacteria was washed off from agar substrate with water. The aqueous suspensions were aligned with each other according to the turbidity standard. The duration of the bacterization of the seeds was 60 minutes. The infectious load was $10^{9} \mathrm{c} / \mathrm{ml}$. In the control, alfalfa seeds were moistened with tap water. Experiment was repeated six times. Plants for analysis were taken at the stems formation ( $36^{\text {th }}$ day after emergence), budding ( $40^{\text {th }}$ day) and flowering ( $46^{\text {th }}$ day). The influence of different norms of PK and inoculation of seeds by nodule bacteria on biometric indices of two components of alfalfa-smooth bromegrass mixture were determined and analyzed. $\mathrm{N}_{2}$-fixation activity (NFA) was determined by acetylene method in terms of acetylene reduction activity of root nodules and expressed in $\mu \mathrm{mol}$ of ethylene, produced by nodules of 1 plant for 1 hour [16]. Roots with nodules were placed in hermetically sealed glass $\left(75 \mathrm{~cm}^{3}\right)$, acetylene of $10 \%$ of the complete vial volume was injected through the rubber membrane with a syringe, having previously removed the same air volume. The incubation time of one sample was 1 hour. A gas mixture containing ethylene, formed as a result of acetylene reduction by nitrogenase, was analyzed on Agilent 
Technologies 6850 Network GC System (USA) gas chromatograph. The volume of the analyzed sample was $1 \mathrm{ml}$.

Acetylene, used in the experiments, was obtained from technical calcium carbide, with followed purification.

Statistical processing of experimental data was carried out in accordance with generally accepted methods [17] with use of Microsoft Excel 2010 software package.

\section{Results and discussion}

Plant growth and development, and legume-rhizobial symbiosis are substantially influenced by various environmental factors and elements of cultivation technology, which often play a decisive role in the realization of the potential of symbionts and the efficiency of this system [18].

As a result of the research carried out it was established that root nodules were formed on all plants of alfalfa, inoculated by strain $S$. meliloti B-7411, at the background of $1,1.5$ and 2 norms of phosphorus and potassium. In this case, positive dynamics of root nodule mass increase during the growing season was noted (Table 1). Significant differences between plants were revealed by the mass of formed nodules depending on the amount of these elements added to the substrate. For example, in the stage of alfalfa stems formation, when it was grown with a smooth bromegrass, the weight of the formed root nodules decreased with increasing phosphorus and potassium nutrition, and was $6.1,5.1$ and $3.4 \mathrm{mg} /$ plant, respectively, for $1,1.5$ and 2 norms PK. A similar trend was noted at the following stages of the active course of assimilation processes in alfalfa. Thus, the weight of the root nodules on alfalfa was significantly less at 1.5 and 2.0 norms in comparison with the weight of the nodules of plants grown under optimal PK standards.

It is known that at low content of phosphorus in the soil, nitrogenfixing bacteria penetrate the root, but do not form nodules [10]. The results obtained by us evidence the inhibitory effect of elevated norms of phosphorus and potassium (1.5 and 2.0 norms) on the nodulation ability of bacteria S. meliloti B-7411 in controlled conditions of pot experiments.

TABLE 1. Mass of alfalfa root nodules and their nitrogen fixation activity for different norms of phosphorus and potassium plant nutrition

\begin{tabular}{l|c|c|c}
\hline \multirow{2}{*}{ PK norm } & \multicolumn{3}{c}{ Development stage } \\
\cline { 2 - 4 } & Stems formation & Budding & Flowering \\
\hline \multicolumn{4}{c}{ Weight of nodules, $\mathrm{mg} /$ plant } \\
1 & $6.1 \pm 0.6$ & $14.0 \pm 1.3$ & $30.6 \pm 3.5$ \\
1.5 & $5.1 \pm 0.6$ & $10.4 \pm 0.6$ & $23.6 \pm 2.2$ \\
2.0 & $3.4 \pm 0.4$ & $8.83 \pm 0.8$ & $15.3 \pm 1.2$ \\
& & & \\
& Nitrogen fixation activity,$\mu$ mol of $\mathrm{C}_{2} \mathrm{H}_{4} /($ plant $\cdot \mathrm{h})$ \\
1 & $0.0418 \pm 0.0045$ & $0.1634 \pm 0.021$ & $0.5912 \pm 0.041$ \\
2.5 & $0.0254 \pm 0.003$ & $0.0816 \pm 0.011$ & $0.4154 \pm 0.046$ \\
& $0.0158 \pm 0.002$ & $0.0456 \pm 0.005$ & $0.202 \pm 0.023$ \\
\hline
\end{tabular}


The mass of root nodules in legume plants is mostly correlated with their molecular nitrogen fixation rate. The general nitrogen fixation activity can serve as an integral index that characterizes the functioning of the symbiotic system, since high nitrogenase activity is observed at the presence of rhizobia specific strain, balance of $\mathrm{C}$ - and $\mathrm{N}$-metabolism in the nodules, and providing of plants by the nutrition elements [19].

In our experiments, the highest level of $\mathrm{N}_{2}$ assimilation by root nodules of alfalfa was observed at the stages of stems formation, budding and flowering at the background of 1 norm phosphorus and potassium, and the decrease of this index in 2.6, 3.6 and 2.9 times at the corresponding stages at the background of 2 norms PK (Table 1).

That is, the symbiotic alfalfa systems formed with the participation of S. meliloti B-7411 at the background of different content of phosphorus and potassium in the substrate differed significantly in nitrogen fixation rate, but had similar dynamics of this index from the stage of stems formation to the flowering stage.

Consequently, the increase in norms of PK from 1 to 1.5 and 2 in the plant cultivation substrate resulted in lowering the nodules mass in 1.21.9 times (in the stems formation stage), 1.3-1.6 (budding) and 1.3-2.0 times (flowering), respectively. Thus, excessive phosphorus and potassium content affects not only the formation of a symbiotic apparatus, but also significantly reduces the nitrogen fixation rate in root nodules.

According to the literary data on experiments with goat's rue plants, clover and soybean the highest nitrogen fixation rates were shown with introducing recommended phosphorus and potassium feeding rates, depending on the soil and climatic zone of cultivation of these crops. With increasing doses of fertilizers, the nitrogen fixation rate gradually decreased [20, 21]. Potassium more strongly affects the effectiveness of symbiosis than phosphorus, due to its participation in the formation, transport and metabolism of sugars in plants [11].

As a result of the research carried out at the Institute of Forage Crops (Bulgaria, Pleven), it has been established that mineral fertilization and soil tillage system also affect the nitrogen use efficiency and the life cycle of alfalfa plants. Thus, the highest nitrogen use efficiency was observed at $\mathrm{N}_{23} \mathrm{P}_{100} \mathrm{~K}_{35}$ and plowing at a depth of $22-24 \mathrm{~cm}$. The most prolonged life cycle of symbiotic formations on the roots of alfalfa was on the background of introducing $\mathrm{N}_{35} \mathrm{P}_{80} \mathrm{~K}_{50}$ and plowing to a depth of 18-22 cm [22].

Consequently, the results we have obtained are corresponded with the literature data that with the increase in the amount of phosphorus and potassium in the plant cultivation substrate, the $\mathrm{N}_{2}$ assimilation rate by alfalfa root nodules decreases.

An important index of the influence of various technological methods and the supply of crops by the elements of nutrition for their growth and development is the dynamics of growth of vegetative mass [7]. As a result of the conducted studies, differences in this index between the plants of different experimental treatments were revealed. In particular, in the treatment without inoculation, the highest growth rates of green mass were noted for 1 norm of phosphorus and potassium, reaching $1.14 \mathrm{~g}$ at the stems formation stage and $1.78 \mathrm{~g}$ at the flowering stage (an increase in the 
aboveground mass of plants between these stages was found $56 \%$ ). With a lower intensity, the aboveground mass of alfalfa increased at 1.5 and 2 norms PK, respectively by 29.4 and $20.7 \%$, yielding to similar indices for optimal (1 norm) PK standards.

Inoculated plants of alfalfa shown the highest growth of green mass from the stems formation stage to the flowering (79 \%) at the background of 1.5 norm PK, while at the same time, at 1 and 2 norms, the growth was 53 and $52 \%$, respectively.

Consequently, the introduction of a double norm of phosphorus and potassium ( 2 norms PK) somewhat slowed the growth of the mass of the alfalfa inoculated and noninoculated plants, compared with those growing at the background of 1 and 1.5 norms.

It should be noted that plants in treatments with inoculation were slightly higher with an increase in the dose of phosphorus and potassium, but had a less massive shoot that was clearly visible visually.

The integral index of the functioning of the legume-rhizobial symbiotic system is usually the yield of the aboveground mass of plants. We carried out two harvestes of mixtures and determined the mass of the resulting fresh and dry matter. Inoculation of seeds with S. meliloti B-7411 bacteria at the background of all doses of phosphorus and potassium resulted in a higher green mass yield of alfalfa compared to non-inoculated plants (Table 2). As a result of the $\mathrm{N}_{2}$ assimilation by nodules, better nitrogen feed conditions are provided, which promotes the intensification of metabolic processes of plant growth and development [3, 5].

The dynamics of growth of the aboveground mass of smooth bromegrass was also positive when growing with alfalfa, inoculated by bacteria, for different rates of input of phosphorus and potassium. At the same time, the smallest values of growth of the green mass of plants of the grass component of mixture were obtained for the introduction of a double norm of PK.

As a result of the bacterization of alfalfa seeds by rhizobia, active plant-microbial symbiotic complexes - root nodules, which actively assimilated atmospheric nitrogen, were formed. Thanks to the symbiotic nitrogen fixation of alfalfa, an additional supply of biological nitrogen to

TABLE 2. Green mass yield of plants in mixtures for different norms of phosphorus and potassium supply and inoculation with nodule bacteria

\begin{tabular}{|c|c|c|c|c|c|c|c|}
\hline \multirow{3}{*}{ Treatments } & \multirow{3}{*}{$\begin{array}{c}\text { Norm } \\
\text { PK }\end{array}$} & \multicolumn{6}{|c|}{ Aboveground mass yield, $\mathrm{g} /$ pot } \\
\hline & & \multicolumn{2}{|c|}{ Fresh weight } & \multirow{2}{*}{$\begin{array}{l}\text { Total } \\
\text { yield }\end{array}$} & \multicolumn{2}{|c|}{ Dry weight } & \multirow{2}{*}{$\begin{array}{l}\text { Total } \\
\text { yield }\end{array}$} \\
\hline & & I harvest & II harvest & & I harvest & II harvest & \\
\hline \multirow{3}{*}{$\begin{array}{l}\text { Without } \\
\text { inoculation }\end{array}$} & 1.0 & $52.10 \pm 2.6$ & $38.41 \pm 3.3$ & 90.51 & $14.82 \pm 0.8$ & $10.34 \pm 1.17$ & 25.16 \\
\hline & 1.5 & $50.55 \pm 1.3$ & $36.27 \pm 1.6$ & 86.82 & $12.82 \pm 1.2$ & $9.21 \pm 0.45$ & 22.03 \\
\hline & 2.0 & $48.26 \pm 6.14$ & $39.03 \pm 2.7$ & 87.29 & $11.97 \pm 1.6$ & $9.61 \pm 0,51$ & 21.58 \\
\hline \multirow{3}{*}{$\begin{array}{l}\text { Inoculation } \\
\text { S. meliloti B-7411 }\end{array}$} & 1.0 & $66.23 \pm 3.9$ & $45.89 \pm 3.4$ & 112.12 & $18.32 \pm 1.5$ & $11.93 \pm 0.78$ & 30.25 \\
\hline & 1.5 & $64.12 \pm 5.6$ & $47.15 \pm 3.1$ & 111.27 & $18.95 \pm 1.1$ & $13.84 \pm 1.7$ & 32.79 \\
\hline & 2.0 & $63.33 \pm 6.8$ & $44.29 \pm 1.3$ & 107.62 & $16.89 \pm 2.5$ & $11.30 \pm 1.12$ & 28.19 \\
\hline
\end{tabular}


the root system of plants had a positive effect on the growth and development of plants of smooth bromegrass.

Studies carried out by Kurgan [23] have proved that the inclusion of perennial legumes in sowing coenoses removed nitrogen from 102 to $200 \mathrm{~kg} / \mathrm{ha}$ by yield of dry matter per one hectare. Davyduk and others [24] indicate that legumes in late-grass mixture sowing to symbiotic nitrogen fixation replaced mineral nitrogen of $98-110 \mathrm{~kg} / \mathrm{ha}$ by the yield of dry matter, and of $140-159 \mathrm{~kg} / \mathrm{ha}$ by the output of digestible protein. According to the Institute of Forages of NAAN of Ukraine [25], legume-grass mixtures included two legume components, provided almost the same dry matter yields, as mixtures without legumes, but which were fertilized by $180 \mathrm{~kg} / \mathrm{ha}$ of nitrogen. The dependence of the nitrogen fixation rate on the species composition of the cultivated grass-legume mixtures was also noted [8].

As a result of our research, the highest indices of productivity of mixture (for the first harvest) were obtained for one norm of PK in the substrate of plant cultivation. Performance indices in the treatments without inoculation were 21.2-23.8\% lower, compared with those in the treatments with the inoculation of $S$. meliloti B-7411. From pots in which the inoculated alfalfa seeds were sown, it was received 14.1, 13.6 and $15.1 \mathrm{~g} /$ pot more green mass at $1,1.5$ and 2 norms of phosphorus and potassium, respectively, in comparison with non-inoculated plants.

According to the second harvest, mixtures grown on a substrate with 1, 1.5 and 2 norms PK and inoculation of alfalfa with nodules bacteria yielded a green mass crop of $45.89,47.15$ and $44.29 \mathrm{~g} / \mathrm{pot}$, corresponding to an increase of $11,9-23,1 \%$ in comparison with the crop of the respective treatments without inoculation of alfalfa (Table 2).

Thus, the yield of grass mixtures for two harvestes in the treatments without inoculation was $18.9-22 \%$ less than inoculated, while inoculated plants had only a tendency to decrease in the yield when growing at elevated PK norms. Indices of plant productivity were the smallest in growing at the background of a double norm of phosphorus and potassium, which indicates the negative impact of the increased dose of these nutrition elements on the growth and development of both components of mixtures.

In studies [26] for inclusion of legume component in the composition of mixture with the introduction of phosphorus and potassium fertilizers, yield of dry mass of seeded grass was $61.0-77.6 \mathrm{c} / \mathrm{ha}$, which was almost equal to the grain crop yield, which brought $60-120 \mathrm{~kg} / \mathrm{ha}$ of nitrogen. As a result of our studies, the level of accumulation of dry matter in the first harvest demonstrated higher rates, compared with the second. Thus, at the first harvest, it was collected 3.5, 6.1 and $4.9 \mathrm{~g}$ per pot more dry matter when subjected to substrate 1, 1.5 and 2 norms PK, respectively. According to the different rates of phosphorus and potassium, the dry matter of inoculated plants $(\mathrm{g} / \mathrm{pot})$ was greater compared to plant without the treatment with nodule bacteria. That is, the provision of mixture with biological $\mathrm{N}$, which enters the substrate of plants cultivation due to its assimilation with root nodules, stimulates the growth of plants of mixtures, which manifests itself in increasing the mass of vegetative organs and accumulation of dry matter (see Table 2). 
Thus, the optimum supply of plants with phosphorus and potassium at the background of seeds inoculation by the active strain of Rhizobium contributes to the increase of the productivity of alfalfa (Medicago sati$v a$ L.) - smooth bromegrass (Brommus inermis Leyss.) mixtures, which creates all the prerequisites for obtaining a high protein forage and the realization of the main functions in the biologization of agriculture by influencing the soil fertility and the state of the environment.

\section{REFERENCES}

1. Melnichuk, T.M. \& Patyka, V.P. (2011). Microbial inoculants in the system bioorganic agriculture. Collection of scientific articles. $3^{\text {rd }}$ All-Ukrainian congress of ecologists with international participation (pp. 423-426), Vinnytsya [in Ukrainian].

2. Butvina, O.Ju., Tolkachev, N.Z. \& Knjazeva, A.V. (1997). Highly competitive strains of nodule bacteria - the basis of the effectiveness of biopreparations. Mikrobiolohichnyy zhurnal, No. 4, pp. 123-131 [in Russian].

3. Kots, S.Ya. \& Mykhalkiv, L.M. (2005). Physiology of symbiosis and nitrogen nutrition of alfalfa. Kyiv: Logos [in Ukrainian].

4. Elkoca, E., Kantar, F. \& Sahin, F. (2007). Influence of nitrogen fixing and phosphorus solubilizing bacteria on the nodulation, plant growth, and yield of chickpea. Journal of Plant Nutrition, 31, No. 1, pp. 157-171. https://doi.org/10.1080/01904160701742097

5. Patyka, V.P., Kots, S.Ya., Volkohon, V.V., Sherstoboeva, O.V. Melnychuk, T.M., Kalinichenko, A.V. \& Hrynyk, I.V. (2003). Biological Nitrogen. Kyiv: Svit [in Ukrainian].

6. Kozar, O.M. (2002). Selection of single-species and mixed sowings of perennial grasses for making of higher productivity hay-mowing in the conditions of Forest-Steppe Right bank of Ukraine. Visnyk NAU, 48, pp. 211-216 [in Ukrainian].

7. Mashchak, Ya.İ., Mizernik, İ.D. \& Nagirnyak, T.B. (2005). Meadows science in theory and practice. Lviv: Spolom [in Ukrainian].

8. Spiridonov, A.M. (2011). Nitrogen-fixing of leguminous plants and meadow agrophytocoenosis with their participation, depending on the composition and character of use. Agrohymycheskyj vestnyk, No. 6, pp. 12-14 [in Russian].

9. Sheudzhen, A.Kh., Khurum, Kh.D. \& Onishchenko, L.M. (2005). Fertilization of lucerne. Maykop: GURIPP "Adygeya” [in Russian].

10. Mishustin, E.N. \& Shilnikov, V.K. (1973). Rhizobia and process of inoculation. Moscow: Nauka [in Russian].

11. Kots, S.Ya. \& Peterson, N.V. (2009). Mineral elements and fertilizers in plant nutrition. Kyiv: Logos [in Ukrainian].

12. Ilieva, A. \& Vasileva, V. (2013). Effect of mineral fertilization and manure on some characteristics in alfalfa (Medicago sativa L.). World Applied Sciences Journal, 26 (5), pp. 630-635. https://doi.org/10.5829/idosi.wasj.2013.26.05.13501

13. Prevon, J.J. \& Harwig, V.A. (1997). Phosphorus deficiency increases the argon-induced decline of nodule nitrogenase activity in soybean and alfalfa. Planta, 201, No. 4, pp. 463469. https://doi.org/10.1007/s004250050090

14. Grodzinskiy, A.M. \& Grodzinskiy, D.M. (1973). A short handbook to plant physiology. Kyiv: Naukova dumka [in Russian].

15. Pat. 111391 UA, IPC C12N1/20, C05F11/08, C12R1/01, Bacteria strain Sinorhizobium meliloti IMB B-7411 for producing bacterial fertilizers for lucerne, Kots, S.Ya., Vorobey, N.A., Publ. 25.04.2016 [in Ukrainian].

16. Hardy, R.W.F., Holsten, R.D., Jackson, E.K. \& Burns, R.C. (1969). The acetyleneethylene assay for $\mathrm{N}_{2}$ fixation: laboratory and field evaluation. Plant Physiol., 42, No. 8, pp. 1185-1207. https://doi.org/10.1104/pp.43.8.1185

17. Dospehov, B.A. (1985). The methodology of field experiment (with the basics of statistical processing of results). Moscow: Ahropromizdat [in Russian].

18. Lapinskas, E. (1998). Biological fixation of nitrogen. Dotnuva: Akademija [in Lithuanian]. 
19. Spaink, H.P., Kondorosi, A., Hooykaas, P.J.J. (Eds.) Tikhonovich, I.A. Provorov, N.A. (Russian Trans., Eds.). (2002). The Rhizobiaceae. Molecular Biology of Model PlantAssociated Bacteria. Sankt-Peterburg [in Russian].

20. Collins, M., Lang, D.J. \& Kelling, K.A. (1986). Effects of phosphorus, potassium, and sulfur on alfalfa nitrogen-fixation under field conditions. Agronomy Journal, 78, No. 6, pp. 959-963. https://doi.org/10.2134/agronj1986.00021962007800060005x

21. Tomar, R.K.S., Raghu, J.S. \& Yadav, L.N. (1991). Effect of phosphorus, rhizobium inoculation and zinc on the yield of soybean (Glycine max L.). International journal of tropical agriculture, 9, No. 3, pp. 211-214.

22. Vasileva, V. \& Pachev, I. (2015). Nitrogen use efficiency and life cycle of nodules in alfalfa after different mineral fertilization and soil cultivation. Global J. Environ. Sci. Manage, 1 (4), pp. 333-339. https://doi.org/10.7508/gjesm.2015.04.008

23. Kurgak, V.G. \& Gorkusha, S.P. (1997). Varieties and variety mixes of value of perennial legume grasses in increase of sown meadows productivity. Zbirnyk naukovyh prac NNC "Instytut Zemlerobstva", 1, pp. 26-28 [in Ukrainian].

24. Davydyuk, M.F., Belash, V. A. \& Kochyk, G.M. (2001). Creation of high productivity of hay-moving by resourse saving technology. Kormy i kormovyrobnyctvo, 47, pp. 207210 [in Ukrainian].

25. Makarenko, P.S. \& Derkach, V.S. (2004). Role of top and bottom thin-stem grasses while creating grasses of pasture and mowing utilization. Kormy i kormovyrobnyctvo, 54, pp. 61-65 [in Ukrainian].

26. Dudchenko, V.I., Golub, S.M. \& Kharchuk, A.S. (2007). Productivity of sown and natural grasses of pasture use depending on the level of fertilization and the composition of grass mix in the conditions of the western Polissya of Ukraine. Foothill and mountain agriculture and stockbreeding, 49, pp. 54-57 [in Ukrainian].

Received 16.08.2019

\title{
ЕФЕКТИВНІСТЬ ЇНОКУЛЯЦІЇ ЛЮЦЕРНИ БУЛЬБОЧКОВИМИ БАКТЕРІЯМИ ПРИ ЇЇ ВИРОЩУВАННІ У ТРАВОСУМІШІ ЗІ СТОКОЛОСОМ БЕЗОСТИМ НА ФОНІ РІЗЗИХ ДОЗ ФОСФОРНО-КАЛІЙНОГО ЖИВЛЕННЯ
}

\author{
П.П. Пухтаєвич ${ }^{1}$ К.П. Кукол ${ }^{1}$, Н.А. Воробейу ${ }^{1}$ В. Васільєва ${ }^{2}$, С.Я. Коць ${ }^{1}$ \\ ${ }^{1}$ Інститут фізіології рослин і генетики Національної академії наук України, Київ \\ e-mail: azot@ifrg.kiev.ua \\ ${ }^{2}$ Iнститут кормових культур, Плевен, Болгарія \\ e-mail: viliana.vasileva@gmail.com
}

В умовах модельного вегетаційного досліду вивчали ефективність інокуляції люцерни бульбочковими бактеріями Sinorhizobium meliloti B-7411 при вирощуванні ії̈ у травосуміші зі стоколосом безостим на фоні різних норм фосфорно-калійного живлення. У результаті проведених досліджень встановлено, що симбіотичні системи люцерни, утворені за участю штаму $S$. meliloti B-7411, відрізнялися за інтенсивністю асиміляції $\mathrm{N}_{2}$ залежно від дози фосфорно-калійного живлення рослин, але мали подібну динаміку зростання цього показника від фази стеблування до фази цвітіння. Відмічено зниження кількості та маси кореневих бульбочок у люцерни за подвійної норми РК, що призводило до зменшення інтенсивності біологічної фіксації атмосферного азоту. Найвищий рівень асиміляції $\mathrm{N}_{2}$ кореневими бульбочками люцерни встановлено у фази стеблування, бутонізації та цвітіння на фоні 1 норми фосфору та калію (за Гельригелем) і зниження цього показника у 2,6, 3,6 та 2,9 раза у відповідні фази на фоні 2 норм РК. Бактеризація насіння люцерни сприяла росту надземної маси рослин обох компонентів травосуміші. У варіантах досліду за передпосівної інокуляції насіння ризобіями $S$. meliloti B-7411 та без інокуляції на фоні 1 норми фосфору і калію отримано найбільший урожай зеленої маси та сухої речовини люцерни порівняно з аналогічними показниками при застосуванні підвищених доз РК (1,5 та 2 норми). Відмічено також позитивну динаміку наростання вегетативної маси стоколосу безостого при вирощуванні у травосуміші з люцерною за різних норм внесення 
фосфору і калію. При цьому найменші показники наростання зеленої маси рослин злакового компонента травосуміші отримано також за внесення подвійної норми РК.

Ключові слова: Sinorhizobium meliloti, люцерна, стоколос безостий, фосфор, калій, інокуляція, азотфіксація, продуктивність.

\section{ЭФФЕКТИВНОСТЬ ИНОКУЛЯЦИИ ЛЮЦЕРНЫ КЛУБЕНЬКОВЫМИ БАКТЕРИЯМИ ПРИ ЕЕ ВЫРАЩИВАНИИ В ТРАВОСМЕСИ С КОСТРОМ БЕЗОСТЫМ НА ФОНЕ РАЗЛИЧНЫХ ДОЗ ФОСФОРНО-КАЛИЙНОГО ПИТАНИЯ}

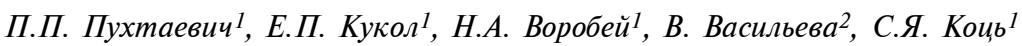

${ }^{1}$ Институт физиологии растений и генетики Национальной академии наук Украины, Киев

${ }^{2}$ Институт кормовых культур, Плевен, Болгария

В условиях модельного вегетационного опыта изучали эффективность инокуляции люцерны клубеньковыми бактериями Sinorhizobium meliloti B-7411 при выращивании ее в травосмеси с костром безостым на фоне различных норм фосфорно-калийного питания. В результате проведенных исследований установлено, что симбиотические системы люцерны, образованные с участием штамма $S$. meliloti B-7411, отличались по интенсивности ассимиляции $\mathrm{N}_{2}$ в зависимости от дозы фосфорно-калийного питания растений, но имели сходную динамику роста этого показателя от фазы стеблевания к фазе цветения. Отмечено снижение количества и массы корневых клубеньков у люцерны при двойной норме РК, что приводило к уменьшению интенсивности биологической фиксации атмосферного азота. Самый высокий уровень ассимиляции $\mathrm{N}_{2}$ корневыми клубеньками люцерны установлен в фазы стеблевания, бутонизации и цветения на фоне 1 нормы фосфора и калия (по Гельригелю) и снижение этого показателя в 2,6, 3,6 и 2,9 раза в соответствующие фазы на фоне 2 норм РК. Бактеризация семян люцерны способствовала росту надземной массы растений обоих компонентов травосмеси. В вариантах опыта с использованием предпосевной инокуляции семян ризобиями $S$. meliloti B-7411 и без инокуляции на фоне 1 нормы фосфора и калия получен наибольший урожай зеленой массы и сухого вещества люцерны по сравнению с аналогичными показателями при применении повышенных доз РК (1,5 и 2 нормы). Отмечена также положительная динамика нарастания вегетативной массы костра безостого при выращивании в травосмеси с люцерной при различных нормах внесения фосфора и калия. При этом наименьшие показатели нарастания зеленой массы растений злакового компонента травосмеси получены также при внесении двойной нормы РК.

Ключевые слова: Sinorhizobium meliloti, люцерна, костер безостый, фосфор, калий, инокуляция, азотфиксация, продуктивность. 